
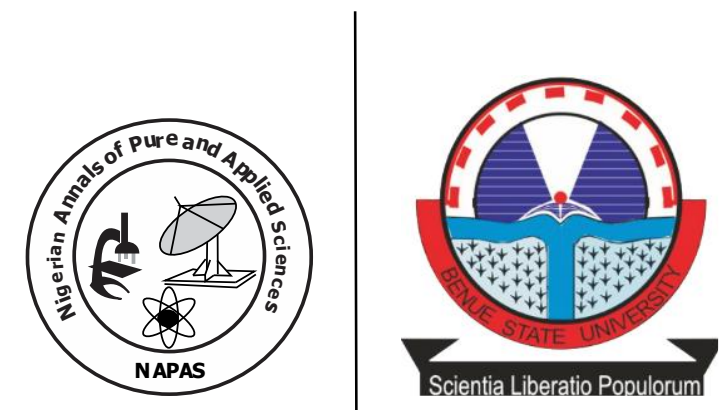

\title{
Effect of Germination Duration on the Chemical Composition, functional and Pasting Properties of Acha Flour and its Potential for Biscuit Production
}

\author{
Ayo, J.A.,"Agbatutu, A. and Iribom, G. K. \\ Department of Food Science and Technology, \\ Federal University Wukari, Wuakari, Nigeria \\ Department of Biological Sciences, Kwarafa University, Wukari \\ Correspondence: jeromeayo@yahoo.com / jeromeayo@gmail.com
}

\begin{abstract}
Germinated acha flour was prepared by washing the acha grain (with tap water), soaking(for 6hours), drained, spread evenly on jute bag to germinate for varied duration $(0,12,24,36$ and $48 \mathrm{~h}$ ). The varied germinated grains were dried in a hot air oven at $60^{\circ} \mathrm{C}$, milled, sieved and packaged in high density polyethylene. The functional, proximate, pasting, mineral and vitamin properties of the germinated flour were determined using standard laboratory procedures. Biscuit produced from the germinated acha flour were also analysed for physical and sensory properties. Biscuit with $100 \%$ wheat flour (WF) serves as a reference sample. The proximate results of the flour showed an increase in protein $(15.38 \%$ to $12.93 \%)$, ash $(3.54 \%$ to $0.58 \%)$, fat ( $8.08 \%$ to $5.12 \%)$, crude fibre $(0.32 \%$ to $0.22 \%)$, but decrease in moisture (11.46\% to $10.15 \%)$, carbohydrate $(69.19 \%$ to $64.56 \%)$ content with increase in germination duration. The pasting properties of the flour, peak viscosity, trough, breakdown, final viscosity, set back, peak time and pasting temperature decreased from 1457.01 to $348.01,1147.07$ to $152.02,310.01$ to $164.02,3306.02$ to $569.01,2159.02$ to $417.02,5.60$ to 5.08 and 1397.44 to $289.17 \mathrm{RVU}$, respectively, with increase in germination duration. There was remarkable increase in the iron, zinc, vitamin B1and B2 content from 22.02 to $93.24,49.01$ to $69.01,0.615$ to 1.633 and 0.163 to $0.483 \mathrm{mg} / 100 \mathrm{~g}$, respectively, and a decrease in the calcium and phosphorus content from 24605.53 to 18498.55 and 1124.94 to $894.960 \mathrm{mg} / 100 \mathrm{~g}$, respectively, with increase in germination time. The weight and spread ratio of the baked germinated acha flour increased from $11.73 \mathrm{~g}$ to $11.43 \mathrm{~g}$ and 4.80 to 4.27 , respectively, while the break strength and the volume of the same, increased from 2.47 to $2.83 \mathrm{~kg}$ and 60.43 to $61.58 \mathrm{~cm}^{3}$ respectively, with increase (1-5days) in germination duration. All the sensory parameters of the biscuits assessed with exception of taste were accepted and compared favourably with the control (100\% wheat biscuit).
\end{abstract}

Key words: Acha, germination, flour, biscuits, quality 


\section{Introduction}

Acha (Digitaria exilis) is an annual cereal crop indigenous to West Africa is and cultivated for its straw and edible grains (Jideani, 2011). The consumption of cereal foods such as biscuit has become very popular in Nigeria especially among children. Acha, (Digitaria exilis) is also known as fundi,fonio, hungry rice, fonio blanch and petit mil, is a grass indigenous to West Africa. Acha, though neglected, is probably the oldest African cereal (Lasekan 1996, NRC, 1985). Even though few other people have ever heard of it, this crop remains important in areas scattered from Cape Verde to Lake Chad. In certain regions of Mali, Burkina Faso, Guinea, and Nigeria, for instance, it is either the staple or a major part of the diets (Lasekan 1996).

Lacking the interest and support of authorities (most of non-African colonial authorities, missionaries, and agricultural researchers) the local grain, acha could not keep pace with the up-to-the minute foreign cereals (wheat, barley), which were made especially convenient to consumers by the use of mills and processing. The old grains languished and remained principally as the food of the poor and rural areas. Whereas, Jideani (2011) further explained that it is widely grown in Nigeria in the cool region of Plateau State, part of Bauchi, Kebbi, Taraba, Kaduna and Niger State. It is either as the stable food or major part of the diet. Each year West African farmers devoted approximately 300,000 ha to acha cultivation and yields of 600-700 kg haGI are regarded which translate to $180,000-210,000$ tonnes of grains annually. The crop supplies food to 3-4 million people and the crop grows well on poor, sandy or ironstone soil in areas of low rainfall (Jideani, 2011).

The consumption of cereal foods such as biscuit has become very popular in Nigeria especially among children. Most of these cereal foods are poor in protein content and protein quality (Alobo, 2001). Aguet al(2014) pointed out that the production of quality biscuit would depend on selecting the correct flour for each type and appropriate processes involving steps such as mixing, aeration and fermentation, machining include laminating, baking, cooling and packaging.
Indeed, Nigeria obviously must proceed at a much faster pace to redress the very grave situation implied by the current virtual dependence on imported raw materials including wheat and that many of the under-utilized food crops indigenous to the third world areas, particularly Nigeria that are neglected by researchers and policy makers should be considered (Ayo et al.,2004).

Acha contains $8-11 \%$ protein which are not easily extractable. However, their digestibility are better than those of sorghum and millet. It is among the most nutritious of all grains because they are rich in methionine and cysteine.as mentioned by Jideani (2011). The high levels of residue protein in it may have important functional properties (Ayo et al., 2004). Acha is also among the world's best cereal, which has good taste. This combination of nutrition and taste has outstanding potentials for the Acha. It is known that acha products based on intact cereal kernel evoke small increase in blood glucose. Millet is also known to contain a relatively high proportion of unavailable carbohydrate and the release of sugar from millet-based diets (Ayo et al., 2004). These factors could be best utilized in developing special foods for diabetics.

Acha has showed a high-water absorption capacity, a property that could be linked to appreciable amounts of pentosans. Acha contains $33 \mathrm{~g} / \mathrm{kg}$ pentosan. The high-water absorption capacity of Acha could be utilized in baked goods.(Ayo et al., 2004).

Germination is a processing method that enhances the nutritional and functional properties of grains as well as their digestibility (Imtiaz and Burhan-Uddin, 2012). Germination occurs when the grain is rehydrated causing an increase in metabolic activities because of reactivation of hitherto dormant enzymes. The metabolic activity results in the production of primary and secondary metabolites thereby improving the nutritional and functional properties of the grain (Bohoua and Yelakam, 2007, Abbas and Mushara, 2008). The main objective of this study was to determine the effects of germination of acha grain on the chemical composition, functional properties of acha flour and its biscuit baking potential. The 
potential of using germinated acha for biscuits production was investigated

\section{Materials and Methods \\ Materials}

Acha (D. exilis) (white cultivar) were purchased from Jos Market, Jos, Nigeria. The grains were manually cleaned to remove stones, damaged and discoloured grains and other extraneous materials. This was achieved through winnowing, sieving and hand picking. Subsequently, the grains were packaged in polythene and covered from where samples were taken for processing and analysis.

\section{Methods \\ Preparation of germinated acha flour}

Germination was carried out as described by Ocheme (2007) with some modifications. $3.3 \mathrm{~kg}$ of cleaned un-dehulledacha grains were washed with tap water and then soaked in 6.5 liters of tap water for 6 hours, drained, evenly spread on jute bags and covered with the same material in a dark, secluded area and allowed to germinate for $0,12,24,36,48$ and 60 hours. Water was sprinkled on the germinating grains at 6 hour intervals to prevent drying out. At the end of each germination period, the grains were dried in a hot air oven at $60{ }^{\circ} \mathrm{C}$ for 8 hour. The rootlets were removed by rubbing the grains between palms. It was then winnowed, milled (using attrition mill), sieved $0.25 \mathrm{~mm}$ mesh) and packaged in high density polyethylene.

\section{Preparation of biscuits}

Forty percent (40\%) Fat was mixed with $60 \%$ potato flour, and added to $100 \%$ germinated acha flour produced at varied germination duration and mixed with other principal materials $(0.1 \%$ salt, $1.0 \%$ baking powder and $3.5 \%$ water) to form batter. The batter was rolled (on a steel table), cut into shape (using biscuit cutter), placed on greased trays and baked at $160^{\circ} \mathrm{C}$ for 20 minutes (Ayo et al., 2014).

\section{Analytical Methods}

Proximate Analysis: The moisture, crude protein, crude fat, ash and carbohydrate content were determined as described by AOAC (2012) while crude fiber content as described by James (1995).

\section{Determination of the functional properties}

The bulk density, foaming, swelling, water absorption and oil absorption capacity were determined as described Onwuka (2005).

\section{Determination of pasting properties}

Pasting characteristics were determined using a Rapid Visco Analyzer (Model RVA 3D+. Newport Scientific Australia). 2.5g of the sample of the germinated acha flour was weighed into a previously dried canister and 25 $\mathrm{ml}$ of distilled water was dispensed into the canister containing the sample. The suspension was thoroughly mixed and the canister was fitted into the Rapid Visco Analyser as recommended. Each suspension was kept at $50^{\circ} \mathrm{C}$ for $1 \mathrm{~min}$ and then heated up to $95^{\circ} \mathrm{C}$ with a holding time of $2 \mathrm{~min}$ followed by cooling to $50^{\circ} \mathrm{C}$ with $2 \mathrm{~min}$ holding time. The rate of heating and cooling were at a constant rate of $11.85^{\circ} \mathrm{C}$ per min. Peak viscosity, trough, breakdown, final viscosity, set back, are read from the pasting profile with the aid of thermocline for windows software connected to a computer (Newport Scientific, 2001).

\section{Determination of minerals and vitamin}

The phosphorous, iron, zinc, calcium and Vitamin B1 of the acha-guavah flour blends were determined as described by AOAC (2012) methods while the $\mathrm{B} 2$ content was determined by direct calorimetric method as described by Kalia (2002)

\section{Sensory attributes determination}

The sensory attributes of the biscuit from germinated acha flour was determined by a 20 member panel (randomly selected among the students and staff of the Department of Food Science and Technology, Federal University Wukari, Nigeria) to evaluate the colour, aroma, texture, stickiness, taste, mouth feel, and overall acceptability of the biscuits using a 9-point Hedonic scale (where $9=$ like extremely- $1=$ dislike extremely). The average mean scores were analyzed statistically.

\section{Statistical Analysis}

One-way analysis of variance (ANOVA) was conducted on each of the variables and the least significant difference (LSD) test at significant level $\mathrm{p}=0.05$ was performed using 
SPSS 20 software for windows to compare the difference between treatment means.

\section{Results}

\section{Proximate Composition of Germinated Acha} Flour

The moisture and the carbohydrate content of the germinated acha grains decreased from 11.5 to 10.2 and 69.2 to $64.6 \%$, respectively, while the ash, protein, fats, and fibre content increased from 0.59 to $3.55,12.9$ to $15.4,5.1$ to 8.1 and 0.24 to $0.35 \%$, respectively, with increase in duration of germination (Table 1).

\section{Functional Properties of Acha flour as Affected by Germination}

The effect of germination on the functional properties of acha flour is shown in Table 2. The bulk density, water absorption capacity, swelling index, foaming capacity and oil absorption capacity of the ungerminatedacha flour(with germination duration of $0 \mathrm{hr}$ ) are $0.64 \mathrm{~g} / \mathrm{g}, \quad 4.67 \mathrm{ml} / \mathrm{g}, \quad 5.83 \mathrm{ml} / \mathrm{g}, \quad 1.85 \mathrm{ml} / \mathrm{g}$ and $2.00 \mathrm{ml} / \mathrm{g}$, respectively.

The swelling capacity, oil absorption capacity and water absorption capacity of the germinated flours decreased from 5.83 to 5.30, 2.00 to 1.77 and 4.67 to $3.70 \mathrm{ml} / \mathrm{g}$, respectively, with increase $(0-48 \mathrm{hr})$ in duration of germination.

The decrease in swelling index, water absorption capacity and oil absorption capacity of the germinated flours were only significant at germination duration above $36 \mathrm{hrs}$. The water absorption capacity of the germinated acha flour at 48 hours $(3.70 \mathrm{ml} / \mathrm{g})$ was significantly higher than that of the control sample $2.73 \mathrm{ml} / \mathrm{g}$ which could be due to the presence of hydrophobic substances in the germinated acha flour than in the control. The bulk density and foaming capacity of the germinated acha flours increased from 0.64 to 0.70 and 1.85 to $5.42 \mathrm{ml} / \mathrm{g}$ respectively. Germination duration effects were only significant at above $24 \mathrm{hrs}$.

\section{Physical Properties of germinated acha biscuits}

The spread ratio and weight of the acha flour decreased significantly $(\mathrm{p}=0.05)$ from 4.88 to 4.27 and 11.73 to $11.43 \mathrm{~g}$, respectively, while the breaking index and volume of the flour increased from 2.47 to $2.83 \mathrm{~kg}$ and 60.4 to $61.58 \mathrm{~cm}^{3}$, respectively, as germination duration increased from $0-48 \mathrm{~h}$ (Table 3 ).

Table 1: Proximate Composition (\%) of Germinated Acha Flour

\begin{tabular}{ccccccc}
\hline $\begin{array}{c}\text { Germination } \\
\text { Duration }\end{array}$ & $\begin{array}{c}\text { Moisture } \\
\text { Content }(\%)\end{array}$ & $\begin{array}{c}\text { Ash content } \\
(\%)\end{array}$ & $\begin{array}{c}\text { Crude Protein } \\
(\%)\end{array}$ & $\begin{array}{c}\text { Fat content } \\
(\%)\end{array}$ & $\begin{array}{c}\text { Carbohydrate } \\
(\%)\end{array}$ & $\begin{array}{c}\text { Fiber }(\%) \\
\end{array}$ \\
\hline 0 & $11.5^{\mathrm{a}} \pm .01$ & $0.59^{\mathrm{e}} \pm .00$ & $12.9^{\mathrm{e}} \pm .01$ & $5.1^{\mathrm{a}} \pm .00$ & $69.2^{\mathrm{a}} \pm 3.07$ & $0.24^{\mathrm{b}} \pm .03$ \\
12 & $10.9^{\mathrm{b}} \pm .02$ & $1.14^{\mathrm{d}} \pm .07$ & $13.9^{\mathrm{d}} \pm .02$ & $5.3^{\mathrm{a}} \pm .00$ & $67.5^{\mathrm{b}} \pm 2.01$ & $0.24^{\mathrm{b}} \pm .02$ \\
24 & $10.8^{\mathrm{c}} \pm .07$ & $1.42^{\mathrm{c}} \pm .03$ & $14.1^{\mathrm{c}} \pm .04$ & $6.2^{\mathrm{b}} \pm .00$ & $66.2^{\mathrm{c}} \pm 2.03$ & $0.27^{\mathrm{b}} \pm .01$ \\
36 & $10.6^{\mathrm{d}} \pm .09$ & $1.73^{\mathrm{b}} \pm .04$ & $15.2^{\mathrm{b}} \pm .06$ & $6.6^{\mathrm{b}} \pm .00$ & $65.2^{\mathrm{d}} \pm 3.01$ & $0.31^{\mathrm{a}} \pm .01$ \\
48 & $10.2^{\mathrm{e}} \pm .07$ & $3.55^{\mathrm{a}} \pm .02$ & $15.4^{\mathrm{a}} \pm .01$ & $8.1^{\mathrm{c}} \pm .00$ & $64.6^{\mathrm{e}} \pm 3.02$ & $0.35^{\mathrm{a}} \pm .04$ \\
\hline
\end{tabular}

* Means within each column not followed by the same superscripts are significantly different $(\mathrm{p}=0.05)$ from each other Table 2: Functional properties of germinated Acha flour

\begin{tabular}{clllll}
\hline $\begin{array}{c}\text { Germination } \\
\text { Duration }\end{array}$ & Bulk Density $(\mathbf{g} / \mathbf{g})$ & $\begin{array}{l}\text { Water Absorption } \\
(\mathbf{m l} / \mathbf{g})\end{array}$ & $\begin{array}{l}\text { Swelling } \\
\text { Capacity }(\mathbf{m l} / \mathbf{g})\end{array}$ & $\begin{array}{l}\text { Foaming } \\
\text { Capacity }(\mathbf{m l} / \mathbf{g})\end{array}$ & $\begin{array}{l}\text { Oil } \\
\text { Absorption } \\
(\mathbf{m l} / \mathbf{g})\end{array}$ \\
\hline $\mathbf{0 ~ h r}$ & $0.64 \pm 0.01^{\mathrm{a}}$ & $3.70 \pm 0.23^{\mathrm{a}}$ & $5.83 \pm 0.06^{\mathrm{a}}$ & $1.85 \pm 0.00^{\mathrm{a}}$ & $1.73 \pm 0.17^{\mathrm{a}}$ \\
$\mathbf{1 2} \mathbf{~ h r}$ & $0.72 \pm 0.01^{\mathrm{b}}$ & $4.47 \pm 0.17^{\mathrm{a}}$ & $5.93 \pm 0.12^{\mathrm{a}}$ & $4.79 \pm 1.00^{\mathrm{be}}$ & $1.80 \pm 0.17^{\mathrm{ac}}$ \\
$\mathbf{2 4} \mathbf{h r}$ & $0.69 \pm 0.01^{\mathrm{b}}$ & $4.53 \pm 0.01^{\mathrm{a}}$ & $5.57 \pm 0.05^{\mathrm{a}}$ & $4.80 \pm 0.00^{\mathrm{ba}}$ & $1.80 \pm 0.15^{\mathrm{ab}}$ \\
$\mathbf{3 6} \mathbf{~ h r}$ & $0.60 \pm 0.01^{\mathrm{b}}$ & $4.60 \pm 0.29^{\mathrm{a}}$ & $5.33 \pm 0.06^{\mathrm{b}}$ & $4.82 \pm 0.00^{\mathrm{a}}$ & $1.83 \pm 0.12^{\mathrm{bcd}}$ \\
$\mathbf{4 8} \mathbf{~ h r}$ & $0.55 \pm 0.00^{\mathrm{a}}$ & $3.70 \pm 0.00^{\mathrm{b}}$ & $5.30 \pm 0.17^{\mathrm{c}}$ & $5.42 \pm 0.06^{\mathrm{ce}}$ & $1.85 \pm 0.12^{\mathrm{acd}}$ \\
$\mathbf{W h e a t}$ & $0.60 \pm 0.01^{\mathrm{b}}$ & $4.73 \pm 0.12^{\mathrm{c}}$ & $8.77 \pm 0.12^{\mathrm{d}}$ & $3.81 \pm 1.95^{\mathrm{de}}$ & $2.00 \pm 0.12^{\mathrm{acd}}$ \\
\hline
\end{tabular}

* Means within each column not followed by the same superscripts are significantly different $(\mathrm{p}=0.05)$ from each other... 
Table 3: Physical Properties of germinated acha flour biscuits

\begin{tabular}{lllll}
\hline $\begin{array}{l}\text { Germination } \\
\text { Duration(hr) }\end{array}$ & $\begin{array}{l}\text { Spread } \\
\text { Ratio }\end{array}$ & $\begin{array}{l}\text { Breaking } \\
\text { Strength }(\mathbf{k g})\end{array}$ & Weight $(\mathbf{g})$ & Volume $(\mathbf{c m 3})$ \\
\hline $\mathbf{0}$ & $4.88 \pm 0.10^{\mathrm{a}}$ & $2.47 \pm 0.06^{\mathrm{a}}$ & $11.73 \pm 0.12^{\mathrm{a}}$ & $61.58 \pm 0.53^{\mathrm{a}}$ \\
$\mathbf{1 2}$ & $4.27 \pm 0.04^{\mathrm{b}}$ & $2.23 \pm 0.06^{\mathrm{b}}$ & $11.5 \pm 0.35^{\mathrm{ac}}$ & $60.43 \pm 1.75^{\mathrm{a}}$ \\
$\mathbf{2 4}$ & $4.30 \pm 0.05^{\mathrm{b}}$ & $2.21 \pm 0.05^{\mathrm{b}}$ & $11.43 \pm 0.12^{\mathrm{ad}}$ & $58.36 \pm 1.56^{\mathrm{b}}$ \\
$\mathbf{3 6}$ & $4.47 \pm 0.05^{\mathrm{bd}}$ & $2.20 \pm 0.06^{\mathrm{c}}$ & $11.3 \pm 0.00^{\mathrm{bcd}}$ & $56.6 \pm 1.29^{\mathrm{c}}$ \\
$\mathbf{4 8}$ & $4.67 \pm 0.00^{\text {be }}$ & $2.00 \pm 0.06^{\mathrm{d}}$ & $11.29 \pm 0.01^{\mathrm{d}}$ & $54 \pm 0.22^{\mathrm{d}}$ \\
$\mathbf{W h e a t}^{\mathrm{d}}$ & $5.01 \pm 0.01^{\mathrm{c}}$ & $5.1 \pm 0.17^{\mathrm{d}}$ & $11.73 \pm 0.23^{\mathrm{a}}$ & $69.86 \pm 3.53^{\mathrm{d}}$ \\
\hline
\end{tabular}

Means within each column not followed by the same superscripts are significantly different $(\mathrm{p}=0.05)$ from each other.

Table 4: Pasting properties of germinated acha flour

\begin{tabular}{llllllll}
\hline $\begin{array}{l}\text { Germination } \\
\text { Duration } \\
(\mathbf{H r})\end{array}$ & $\begin{array}{c}\text { Peak1 } \\
(\mathbf{R V U})\end{array}$ & $\begin{array}{c}\text { Trough1 } \\
(\mathbf{R V U})\end{array}$ & $\begin{array}{c}\text { Break-down } \\
(\mathbf{R V U})\end{array}$ & $\begin{array}{c}\text { Final } \\
\text { Viscosity } \\
(\mathbf{R V U})\end{array}$ & $\begin{array}{c}\text { Setback } \\
(\mathbf{R V U})\end{array}$ & $\begin{array}{c}\text { Peaktime } \\
(\mathbf{m i n s})\end{array}$ & $\begin{array}{c}\text { Psting temp } \\
\left({ }^{\mathbf{0}} \mathbf{C}\right)\end{array}$ \\
\hline 0 & $1457.1^{\mathrm{a}} \pm 10.1$ & $1147.3^{\mathrm{a}} \pm 12.4$ & $310.4^{\mathrm{a}} \pm 5.5$ & $3306.6^{\mathrm{a}} \pm 12.1$ & $2159.1^{\mathrm{a}} \pm 12.1$ & $5.4^{\mathrm{a}} \pm .2$ & $1397.5^{\mathrm{a}} \pm 9.2$ \\
12 & $1208.2^{\mathrm{b}} \pm 11.3$ & $953.2^{\mathrm{b}} \pm 8.3$ & $255.2^{\mathrm{b}} \pm 3.2$ & $3306.4^{\mathrm{a}} \pm 13.4$ & $2159.2^{\mathrm{a}} \pm 11 . .2$ & $5.4^{\mathrm{a}} \pm .2$ & $1397.6^{\mathrm{a}} \pm 8.4$ \\
24 & $1110.0^{\mathrm{c}} \pm 6.0$ & $860.3^{\mathrm{c}} \pm 5.4$ & $189.4^{\mathrm{d}} \pm 3.5$ & $2834.6^{\mathrm{b}} \pm 7.3$ & $1253.2^{\mathrm{b}} \pm 7.3$ & $5.7^{\mathrm{a}} \pm .1$ & $1056.7^{\mathrm{b}} \pm 5.2$ \\
36 & $1004.2^{\mathrm{d}} \pm 6.2$ & $840.3^{\mathrm{d}} \pm 7.4$ & $164.4^{\mathrm{e}} \pm 5.5$ & $1983.4^{\mathrm{c}} \pm 2.5$ & $1143.5^{\mathrm{c}} \pm 5.6$ & $5.6^{\mathrm{a}} \pm .1$ & $856.6^{\mathrm{c}} \pm 3.1$ \\
48 & $348.3^{\mathrm{e}} \pm 2.3$ & $152.3^{\mathrm{e}} \pm 2.3$ & $196.1^{\mathrm{c}} \pm 2.1$ & $569.1^{\mathrm{d}} \pm 4.1$ & $417.2^{\mathrm{d}} \pm 4.2$ & $5.3^{\mathrm{a}} \pm .4$ & $281.4^{\mathrm{d}} \pm 2.2$ \\
\hline
\end{tabular}

*Means within each column not followed by the same superscripts are significantly different $(\mathrm{p}=0.05)$ from each other

Table 5: Mineral and Vitamins Composition of Germinated Acha flour

\begin{tabular}{lcccccc}
\hline $\begin{array}{l}\text { Germination } \\
\text { Duration(Hr) }\end{array}$ & $\begin{array}{c}\text { Iron } \\
(\mathbf{p p m})\end{array}$ & $\begin{array}{c}\text { Calcium } \\
(\mathbf{p p m})\end{array}$ & $\begin{array}{c}\text { Zinc } \\
(\mathbf{p p m})\end{array}$ & $\begin{array}{c}\text { Phosphorus } \\
(\mathbf{p p m})\end{array}$ & $\begin{array}{c}\text { Vitamin } \\
\mathbf{B}_{\mathbf{1}} \\
(\mathbf{m g} / \mathbf{1 0 0 g})\end{array}$ & $\begin{array}{c}\text { Vitamin Bam } \\
(\mathbf{m g} / \mathbf{1 0 0 g})\end{array}$ \\
\hline 0 & & & & & & \\
12 & $22.04^{\mathrm{e}} \pm .02$ & $24605.58^{\mathrm{a}} \pm 76.07$ & $49.26^{\mathrm{e}} \pm 1.35$ & $1124.82^{\mathrm{a}} \pm 12.14$ & $0.64^{\mathrm{c}} \pm .04$ & $0.16^{\mathrm{c}} \pm .00$ \\
24 & $29.63^{\mathrm{d}} \pm .04$ & $23200.05^{\mathrm{b}} \pm 23.04$ & $52.88^{\mathrm{d}} \pm 2.07$ & $878.78^{\mathrm{e}} \pm 14.12$ & $0.72^{\mathrm{c}} \pm .00$ & $0.42^{\mathrm{b}} \pm .02$ \\
36 & $36.04^{\mathrm{c}} \pm .02$ & $22670.02^{\mathrm{c}} \pm 12.02$ & $53.72^{\mathrm{c}} \pm 2.21$ & $989.08^{\mathrm{c}} \pm 9.01$ & $0.82^{\mathrm{b}} \pm .02$ & $0.44^{\mathrm{b}} \pm .00$ \\
48 & $49.04^{\mathrm{b}} \pm .05$ & $21350.02^{\mathrm{d}} \pm 21.01$ & $54.92^{\mathrm{b}} \pm 3.07$ & $999.32^{\mathrm{b}} \pm 6.35$ & $0.85^{\mathrm{b}} \pm .03$ & $0.48^{\mathrm{a}} \pm .01$ \\
\hline
\end{tabular}

*Means within each column not followed by the same superscripts are significantly different $(\mathrm{p}=0.05)$ from each other.

Table 6: Sensory Attributes of Biscuit Produced From Germinated Acha Flour

\begin{tabular}{lllllll}
\hline $\begin{array}{l}\text { Germination } \\
\text { Duration (Hr) }\end{array}$ & Colour & Texture & Taste & Odour & Crispness & Gen, Accpt \\
\hline $\mathbf{0}$ & & & & & & \\
$\mathbf{1 2}$ & $6.20 \pm 1.88 \mathrm{~b}$ & $6.65 \pm 1.66 \mathrm{a}$ & $1.61 \pm 1.61 \mathrm{~b}$ & $6.35 \pm 1.38 \mathrm{~b}$ & $6.00 \pm 1.74 \mathrm{a}$ & $6.90 \pm 1.53 \mathrm{~b}$ \\
$\mathbf{2 4}$ & $6.45 \pm 1.39 \mathrm{~b}$ & $6.90 \pm 1.74 \mathrm{a}$ & $1.70 \pm 1.70 \mathrm{ab}$ & $6.80 \pm 1.32 \mathrm{ab}$ & $6.85 \pm 2.08 \mathrm{a}$ & $6.55 \pm 1.66 \mathrm{~b}$ \\
$\mathbf{3 6}$ & $6.25 \pm 2.09 \mathrm{~b}$ & $6.78 \pm 1.66 \mathrm{a}$ & $1.66 \pm 1.61 \mathrm{~b}$ & $6.58 \pm 1.38 \mathrm{~b}$ & $6.43 \pm 1.74 \mathrm{a}$ & $6.73 \pm 1.53 \mathrm{~b}$ \\
$\mathbf{4 8}$ & $6.95 \pm 1.36 \mathrm{~b}$ & $7.15 \pm 1.72 \mathrm{a}$ & $1.97 \pm 1.97 \mathrm{ab}$ & $6.95 \pm 1.39 \mathrm{ab}$ & $6.85 \pm 1.95 \mathrm{a}$ & $6.95 \pm 1.99 \mathrm{~b}$ \\
Wheat & $6.05 \pm 2.09 \mathrm{~b}$ & $6.55 \pm 1.73 \mathrm{a}$ & $1.60 \pm 1.60 \mathrm{ab}$ & $6.55 \pm 1.79 \mathrm{ab}$ & $6.60 \pm 2.01 \mathrm{a}$ & $6.60 \pm 2.11 \mathrm{~b}$ \\
\hline
\end{tabular}

Values are mean \pm standard deviation of 2 replicates. Means within each column not followed by the same superscripts are significantly different $(\mathrm{p}=0.05)$ from each other using Duncan multiple range test.

\section{Discussion}

Proximate Composition of Germinated Acha Flour

The production of low moisture content of germinated acha flours could reduce the chances of spoilage by micro-organisms and consequently guarantee good storage stability (Ayo et al., 2007). An increase in protein content may be attributed to a passive variation due to decrease in the carbohydrate compound used for respiration. Most of the stored protein of cereals is located in the aleurone part of the grains (bodies) of the aleurone layer, and in the protein bodies of the endosperm. Aleurone layer releases several different proteins which mobilize the reserve proteins of the starchy endosperm.

The high ash content could indicates high levels of minerals in the composite biscuit 
samples (Okaka and Ene, 2005). This suggests that biscuit from the composite flour blends could improve the mineral intakes of the consumers. Omeire and Ohambele (2010) observed a similar trend of increasing ash content (1.65-2.20\%) in biscuit produced from wheat-defatted cashew nut flours which also agreed with Gernah et al., (2010).

The low carbohydrate content and increased fibre content of the flour could have several health benefits, as pointed out by Elleuch et al., (2011) and Slavain, (2005) that could it aid digestion in the colon and reduces constipation often associated with products from refined grain flours.

\section{Functional Properties of Acha Flour as Affected by Germination}

The observed trend of functional properties agreed with the findings of OluOwoladi et. al (2014). Germination increased water absorption capacity of the samples which is contrasted to the work of Imtiaz et al. (2011), but in line with the work of Gernah et al. (2011). The increase observed might have been as a result of the production of compounds having good water holding capacity such as soluble sugars. According to Okaka and Potter (1997), water holding capacity depends on the water bounding capacities of food components. Germination increased oil absorption capacity in line with earlier work of Imtial et al. (2011). Giani and Bekebain (1992) reported that germination of grains enhances the oil absorption capacity due to the entrapment of oil related to the non-polar side chains of proteins.

Krawinkel et al (2012) attributed the decrease in swelling index, oil absorption capacity and water absorption capacity of cereal flours during germination to the breaking down of gluten contained in the grain by complex biochemical processes that occur during germination. Ayo et al, (2018) has also explained that the breaking down of thickening structures of the cereal flour to reduce its liquid absorption and holding capacity could reduce swelling.

The increase in bulk density could be attributed to the loss of other digestible components of the grain during germination at various stages. The water absorption capacity describes flour -water association ability under limited water supply. The result suggests that, increased germination duration of up to $48 \mathrm{hr}$ could increase the baking application of the acha flour.

Elkhalifa and Bernhardt (2010) reported an increase in the water absorption capacity of sorghum flour after germination, which could be attributed to an increase in protein quality (e.g., partial unraveling of the protein structure via enzymatic action) upon germination and also the breakdown of polysaccharide molecules. The increase in oil absorption might be due to the dissociation and partial unfolding of polypeptides that expose the hydrophobic sites of amino acids, which aids hydrophobic association of the peptide chains with lipid droplets.

Brou et al. (2013) reported increasing foaming stability with increasing protein content while characterizing complementary food made from maize, millet, beans and soybeans. They further reported higher protein stability for native proteins. The increase in foaming stability observed for sample that germinated for $48 \mathrm{~h}$ might have been as a result of bioavailability of inherent proteins which were probably bound by antinutritional factors such as phytin in the sample.

\section{Physical Properties of germinated acha biscuits}

The decrease in the spread ratio could be due to breaking down and conversion of the grains protein during germination with consequent lowering of gelatinization ability, viscosity and ability to spread prior to baking. The decrease in weight could also be due to the loss of matter and some other components of the flour during reactions that lead to germination. Jideani and Onwubali (2006) reported that, germination could lead to loss of some nutrients in the grain to the sprout leading to loss of weight in the grain. The increase in breaking strength of the acha biscuits baked with germinated acha grain flour could be attributed to the increase in foaming capacity of the flour during germination resulting into strengthening of the carbohydrates to carbohydrates and carbohydrates to protein molecules. Agu et al (2015) reported that, foaming could improve such bonds as well as the breaking strength of baked products. The decrease in weight of the samples with germination time from 11.73 to 
$11.43 \mathrm{~g}$ could help to reduce the heaviness of the flour and that of the products and consequently the transportation cost and post handling of the products.

\section{Functional Properties}

The decrease observed in foaming capacity might have been as a result of denaturation of protein molecules during milling and germination processes. Brouet al. (2013) reported that native protein provide higher foam capacity than denatured protein.

\section{Pasting Properties of Germinated Acha Flour}

The relatively low setback viscosities of flour produced from fermented acha grains could make it suitable for preparing gels with tendencies to synerese (Jideani and Akingbala, 1993). The decrease in the setback viscosity could be due to the higher fibre content of the flour and it could be an advantage in the improvement of the digestibility and low tendency for retro gradation of acha food products. Higher set back values are synonymous with reduced dough digestibility while lower setback during the cooling of the paste indicates a lower tendency for retro gradation.

\section{Mineral and Vitamins Composition of Germinated Acha Flour}

The findings agreed with that of Adam et al (2009). The decrease in calcium and phosphorous content could be due to the binding effects of phytic acid which increased as a result of increased activity of the enzyme phytase during germination (Nkama et al., 2001). The increase in the vitamins agreed with Finny (1982) with significant increases in the concentration of riboflavin, niacin, biotin and pyridoxine during the germination of many kinds of Edible seeds.

The biochemical processes occurring during germination can generate bioactive components such as riboflavin, thiamine, biotin, pantothenic acid, niacin, vitamin $\mathrm{C}$, tocopherols and phenolic compounds, and also increase their availability (Moongngarm and Saetung, 2010). Gilay and Field (1981) reported a 1.8- fold increase in the thiamine, riboflavin and niacin contents of sprouted corn grain.

\section{Sensory Attributes of Biscuit Produced From Germinated Acha Flour}

The breakdown of high molecular weight polymers during germination leads to the generation of bio-functional substances and an improvement in organoleptic qualities due to a softening of texture and an increase in the flavour of various cereals.

\section{Condusion}

Germination is an effective processing method for improving nutritional quality, boosting the level of protein and available carbohydrates, increasing mineral bioavailability, and improving the functional and sensory properties of cereal and pulses based foods. Due to the significant effects of germination, sprouted grains and pulses could become popular and widely accepted as functional foods and functional food ingredients.

\section{References}

Abbas, T.E.E and Mushara, N.A. (2008). The effect of germination of low-tannin sorghum grains on its nutrient content and broiler chicks' performance. Pakistan Journal of Nutrition,7(3), 470474.

Adam F, Villiers E, Watson S, Coyne K, Blackwood L. (2009).Clinical pathological and epidemiological assessment of morphologically and immunologically confirmed canine leukaemia. Vet Comp Oncol. 7(3):18195. doi: 10.1111/j.1476-5829.2009.

Agu, H.O., Ezeh, G.C. and Jideani, A.I.O.

(2014). Quality assessment of Achabased biscuit improved with bambara nut and unripe plantain. African Journal of Food Science, 8 (5): 278-289.

Akpada, M.I and Miachi, O.E. (2001).Proximate composition and selected functional properties of Detariummicrocarpum. Plant foods for Human Nutrition, 56,297-

302.http//dx.doi.org/10.1023/A:1011836 332105

Alobo, A. (2001). Effect of sesame seed flour on millet biscuit characteristics. Plant Food Human Nutrition, 195-200.

Ayo J.A, Ayo V.A, Nkama I and Adewori R (2007). Physio-chemical in-vitro 
digestibility and organoleptic evaluation of acha wheat biscuit supplemented with soybean flour. Nigerian Food Journal. 25(1): 77-89

AOAC (2012) Official Method of Analysis Association of Official Analytical Chemists. 22th Edition, AOAC International Publisher, Washington DC.

Ayo, J.A., Ibrahim, A. and Nkama, I. (2003). Effect of Acha (Digitaria exilis) on the body weight, glucose blood level, haemoglobin and packed column cell of rabbit. Book of abstract, National Conference of the Applicaton of Science for National Development., (p. 56). Mubi, Adamawa State

Ayo, J.A., Ikuomola, D.S. and Esan, Y.O. (2004). Effects of added defatted beniseed on the quality of Acha-based biscuit . Continental Journal of Food Science and Technology, 4:7-13.

Ayo J.A, Ayo V.A, Nkama I and Adewori R (2007). Physio-chemical in-vitro digestibility and organoleptic evaluation of acha wheat biscuit supplemented with soybean flour. Nigerian Food Journal. 25(1): 77-89

Chinma E.C, Anounye J, Omotade C.S, Danbaba N. (2015). Effect of germination on the physical and chemical and antioxidant characteristics of rice from the rice varieties from Nigeria. Food Chemistry (185): 10-16

Elleuch, M et al. (2011) Sesame (SesamumindicumL.) Seeds in Food, Nutrition and Health Nuts \& Seeds in Health and Disease Prevention, 10291036

Finny P.L (1982). Effect of Germination on Cereal and Legume Nutrient Changes and Food or Feed Value: A Comprehensive Review Recent Advances In Phyto-chemistry Volume 17 Mobilization of Reserves in Germination Plenum Press New York and London

Gernah, D.I., Senger, L.A. and Audu, J.O. (2010). Physicochemical and sensory evaluation of cookies produced from wheat and brewers' spent grain composite flour. Nigerian Food Journal 28 (2): 440447.
Imtiaz, H., burhan-Uddin, M., and Gulazar, M. (2011). Evaluation of weaning foods formulated from germinated wheat anfmunbean from Bangladash. African Journal of Food Science, 5(17), 897-903.

James, L.F (1995). Phytochemicals: The good, the bad and the ugly. Phytochemistry. 68: 22-24.

Jideani, I.A. (2012). Digitariaexislis (acha/ fonio), Digitariaiburua (ibura/fonio) and Eleusinecoracona (tamba/finger-millet)Non-conventional cereals grains with potentials. Scientific Research and Essays, 7(45): 3834-3843.

Jideani, I.A and Akingbala, J.O. (1993). Some physiochemical properties of acha (Digitariaexilis staph) and iburu (Digitariaiburua staph) grains. Journal of Food Sciences and Food Agriculture, 63:369-371.

Jideani, I.A. and Jideani, V.A. (2011). Developments on the cereal grains, Digitariaexilis (acha) and Digitariaiburua (iburua). Journal of Food Science and Technology, 48(3):251-259.

Kalia, M. (2002).Food Analysis and Quality Control, Kalyani Pub. New Delhi p.167.

Kwon-Ndung, E.H., Misari, S.M. and Dachi, S.N. (2001). Study on the production practices of Acha (Digitaria exilis Kippis Staph.) in Nigeria. Science Forum, 4 (2): 106-113.

Krawinkel M B (2012). Overcoming under nutrition with local resources in Africa, Asia and Latin America Journal of the Science of Food and Agriculture; 92: 2757-2759.

Lasekan, O.O. (1994). Chemical Composition of Acha (Digitariaexilis) Flour. J Food SciAgric 14:177-179.

National Research Council (NRC), (1996). Lost Crops of Africa (Vol. 1), Grains. National Academy Press, Washington, DC, USA.

New port Scientific (NPS), (2001). Development of an acha (digitariaexilis) dehulling machine. Academy Press, Washington, Dc, USA.

Nkama, I and Gbenyi, D.I (2001).The effect of malting of millet and sorghum on the 
Nigerian Annals of Pure and Applied Science Vol. 2, 2019 |17

residual phytates and polyhpenols in dakuwa - a Nigerian cereal - legume snack food. Nigerian Journal of Tropical Agriculture, 3, 76 - 85.

Ocheme, O.B. (2007). Effect of storage of millet flour on the quality and acceptability of millet flour porridge (Enyiokwolla). Journal of Food Technology, 5(3), 215219.

Olapade A.A., Akingbala J.O., Oguntunde A.O and Falake K,O (2003). Effect of processing method on the quality of cowpea (vignaunguiculata) flour for akara preparation .plant for Human Nutrition.58:1-10

Olu-Owolabi B I, Olayinka O O, Adegbemile A A and K O Adebowale (2014). Comparison of functional properties between native and chemically modified starches from Acha (Digitariaexilis Stap) grains. Food and Nutrition Sciences; 5: 222-230 